\title{
MASKULINITAS DALAM MEDIA ONLINE: ANALISIS WACANA KRITIS DALAM KAJIAN CERAMAH USTADZ SALAF
}

\author{
Ahmad Abdullah Rosyid \\ Magister Kajian Sastra dan Budaya, Universitas Airlangga \\ rossie.pqr@gmail.com
}

\begin{abstract}
ABSTRAK
Media is an intermediary that is widely used in conveying information, such as print media, visual media (television), and online visual media. The information contained a lot about ideology, hegemony, power, and even marginalization. The media is also very influential in affirming the concept of gender in society, one of which is YouTube's online media which is considered the most effective in disseminating information. Various kinds of accounts publish videos with various concepts, some contain games, some have vlogs, and some contain lectures. In this paper, the researcher will discuss the contents of the lecture delivered by Ustadz Khalid on gender issues, such as differences between men and women and the characteristics of a man towards women. Three shows were taken as samples and analyzed using Norman Fairclough's critical discourse theory which offers three-dimensional concepts in it; textual, discourse, and social. The results obtained were from the three videos, Ustadz Khalid tried to instill ideology in the community. This is in line with the patriarchal family system adopted by the majority of people in Indonesia.
\end{abstract}

Keywords: masculinity, media, discourse analysis, gender

\section{PENDAHULUAN}

Perbedaan dasar antara laki-laki dan perempuan dikategorikan oleh dua konsep, yaitu jenis kelamin (sex) dan gender. Perbedaan jenis kelamin mengacu pada perbedaan fisik, terutama pada perbedaan alat serta fungsi reproduksi. Sementara itu, gender adalah suatu bentukan konstruksi sosiokultural. Gender merupakan interpretasi kultural atas perbedaan jenis kelamin. Gender memang berkaitan dengan perbedaan jenis kelamin, namun tidak selalu berhubungan dengan perbedaan fisiologis seperti yang selama ini sering disalah artikan dalam masyarakat. dalam konsep Gender atribut dan pekerjaan berupa "maskulin" dan "feminim". Gender yang berlaku dalam suatu masyarakat ditentukan oleh pandangan mereka tentang hubungan antara laki-laki dan kelaki-lakian juga antara perempuan dan keperempuanan. Secara umum, jenis kelamin laki-laki diasosiasikan dengan gender maskulin, sedangkan jenis kelamin perempuan dikaitkan dengan gender feminin. Akan tetapi hubungan 
itu bukan merupakan korelasi yang bersifat mutlak (Susilastuti 1993, 30). Dalam hal kedua konsep ini seringkali menjadi bias ketika dimaknai oleh media. Gender oleh media diidentikan dengan jenis kelamin (sex). Dimana maskulinitas diidentikkan dengan lakilaki, sehingga menjadi laki-laki haruslah seperti ini, haruslah yang kuat dan berotot, haruslah perkasa dan sebagainya. sementara feminimitas selalu identik dengan perempuan, sehingga stereotipe yang dibangun oleh media adalah perempuan yang lemah lembut, yang menjaga penampilan dan kecantikan dan sebagainya. hal seperti ini seringkali kita jumpai dalam berbagai macam tayangan di televisi, baik berupa iklan produk-produk yang dikhususkan oleh pria seperti susu penambah nutrisi dan juga suplemen atau vitamin tertentu serta produkproduk kecantikan wanita seperti produk kecantikan dan lain lain, maupun dalam tayangan film serial serta reality show seperti komedi dan sejenisnya.

Wood menjabarkan bahwa kuatnya media menciptakan dan mendeskripsikan stereotipe mengenai laki-laki dan perempuan. Media menggambarkan sosok laki-laki dan maskulinitas sebagai mereka yang agresif, dominan, dan terlibat dalam berbagai kegiatan yang membutuhkan keputusan. Media menggambarkan itu sebagai rewards dari sisi maskulin yang laki-laki miliki. Dalam penelitian Doyle (Doyle 1989, 111), sosok laki-laki oleh media digambarkan sebagai mereka yang tidak peduli dengan sesama, tidak mengasuh anak, dan tidak pernah mengerjakan pekerjaan rumah tangga. Dalam konteks yang sebaliknya, media menampilkan perempuan dengan sisi sebaliknya. Perempuan ditampilkan sebagai sosok yang penuh dramatis. Media hanya menampilkan dikotomi antara perempuan baik dan perempuan tidak baik. Perempuan baik oleh media digambarkan sebagai perempuan cantik, berfokus pada pekerjaan rumah tangga, keluarga, patuh terhadap suami, dan sosok yang mengasihi sesama. Sedangkan mereka yang dikatakan perempuan tidak baik digambarkan sebagai mereka yang berkebalikan dengan standar perempuan baik tersebut (Wood 1984, 234). Meski demikian, konstruksi mengenai ideologi maskulinitas yang dibangun oleh media semakin hari juga mengalami pergeseran. Seperti contoh dalam penelitian yang dilakukan oleh Friska Dewi dan lainnya (Yuliyanti 2017) yang mengambil fokus pada iklan produk grooming pria, terdapat ideologi-ideologi yang dengan sengaja dibentuk oleh iklan tersebut dengan semboyan \#lelakimasakini. Maksudnya adalah bahwa seorang lelaki yang maskulin adalah lelaki yang rajin merawat tubuhnya, perhatian, gemar terhadap hobinya dan juga supel (Yuliyanti 2017:29). Begitu juga dengan pandangan feminitas selalu mengalami pergeseran hingga dewasa ini. Seperti dalam penelitian yang dilakukan oleh Sri Indah Wijayanti (Wijayanti 2019) yang membahas mengenai representasi perempuan dalam iklan kosmetik. Wijayanti menjabarkan bahwa konstruksi yang berusaha ditonjolkan dalam iklan tersebut adalah anggapan masyarakat terhadap perempuan masa kini. Perempuan zaman sekarang digambarkan sebagai perempuan yang dinamis dan aktif sehingga memiliki 
berbagai macam kegiatan baik dalam ruangan maupun di luar ruangan. Sehingga dari representasi tersebut muncullah anggapan masyarakat terhadap perempuan modern yakni perempuan yang aktif, mandiri, dan tidak terkekang oleh orang lain khususnya laki-laki.

Perspektif tersebut jika dikaitkan dengan agama maka akan sejalan. Suatu agama, terutama Islam mengatur sedemikian rupa perilaku manusia bahkan tidak lepas juga dari aturan maskulinitas dan feminitas. Misalnya, dalam suatu hadith terdapat larangan bagi laki-laki yang menyerupai perempuan, baik dari segi penampilan maupun perbuatan, karena hal tersebut dikatakan sebagai keluar dari fitrah/kodrat sebagai laki-laki. Begitu pun sebaliknya, seorang perempuan selayaknya berpenampilan dan berperilaku seperti perempuan, menutup aurat, santun, lemah-lembut, taat terhadap suami dan sebagainya. Jika seorang perempuan berada di luar sifat-sifat tersebut, maka dia juga dianggap keluar dari fitrahnya.

Dengan keterkaitan antara agama dan media tersebut, bukanlah hal yang sulit bagi para pendakwah seperti ustadz atau kyai untuk tampil dan menuturkan ajaran-ajaran agama melalui media. Dalam televisi misalnya, beberapa stasiun televisi menayangkan pengajian rutin setiap harinya, baik pengajian tersebut diisi oleh pendakwah laki-laki maupun perempuan. Umumnya, pengajian ini ditayangkan pada pagi hari berkisar setelah sholat subuh. Selain dari media televisi, dalam media online seperti Facebook, Instagram dan Youtube pun juga dijadikan sebagai media yang efektif untuk menuturkan ajaran para pendakwah. Persoalan yang menyangkut maskulinitas dan feminitas pun sering dibahas. Salah satu media online yang paling besar pengaruh terhadap kajian-kajian yang dibawakan oleh pendakwah adalah Youtube. Beberapa kanal di Youtube sering mengunggah kajian-kajian para pendakwah dari kalangan sufi. Walaupun kanal tersebut bukanlah kanal resmi milik pendakwah tersebut, namun secara konsisten mereka selalu merekam dan mempublikasian kajiankajian para pendakwah secara rutin di masing-masing kanal mereka. Kualitas kajian-kajian yang di publikasikan pun sangat jelas bahkan tidak kalah dengan kajian yang beredar di televisi. Beberapa pendakwah yang sring bermunculan di kanal-kanal Youtub diantaranya adalah Ustadz Abdul Somad, Ustadz Adi Hidayat, dan Ustadz Khalid Basalamah. Ketiga ustadz tersebut terbilang pendakwah populer dimana profil latar belakang pendidikan mereka telah diakui, bahkan mereka menuntut ilmu hingga di luar negeri, dan ada juga yang menjadi dosen, seperti Ustadz Abdul Somad.

Dalam melakukan suatu kajian, para pendakwah tersebut biasanya menyuguhkan suatu tema untuk dijadikan topik tuturan mereka. Terkadang tuturan disampaikan sekitar tiga puluh menit hingga satu jam. Kemudian barulah di buka sesi tanya jawab serta diskusi. Tak jarang para pendakwah juga membawakan tema yang membahas mengenai karakter laki-laki dan perempuan. Dimana hal tersebut berkaitan dengan topik bahasan maskulinitas dan feminitas. Dalam penelitian ini, peneliti akan 
menggunakan kajian-kajian yang dituturkan oleh Ustadz Khalid Basalamah mengenai topik karakter seorang laki-laki. Peneliti menggunakan kajian milik ustadz Khalid karena kajian beliau dinilai yang paling gamblang dan secara kontinu menjelaskan mengenai topik tersebut. Dalam salah satu sesi tanya jawab, terdapat pertanyaan yang keluar dari tema besar pokok bahasan kajian, namun beliau masih bersedia menjawabnya karena pertanyaan tersebut berhubungan dengan hal-hal yang menyangkut karakter seorang lakilaki. Dalam menganalisis topik bahasan tersebut, peniliti ingin menggunakan konsep wacana kritis yang ditawarkan oleh Fairclough meliputi tiga dimensi. Yakni dimensi tekstual, dimensi kewacanaan, serta dimensi sosial.

\section{Kajian Pustaka}

Fairclough mengemukakan bahwa analisis teks merupakan analisis terhadap teks yang terdapat dalam wacana. Teks dinilai sebagai domain representasi dan signifikasi dunia dan pengalaman, dan lain sebagainya. Dan teks terbuka untuk pelbagai interpretasi Fairclough, (Fairclough 1992,75-78). Ada beberapa bentuk atau sifat teks yang dapat dianalisis dalam membongkar makna melalui dimensi tekstual, dalam penelitian ini, peneliti menggunakan analisis repetisi, tema, serta diksi untuk membedah makna dari tuturan Ustadz Khalid. Dalam wilayah ini, diperlukan deskripsi untuk melakukan pemahaman teks agar memperoleh bagaimana suatu teks dipresentasikan. Pada tahap ini juga, Fairclough menekankan penyelidikan secara mendalam terhadap proses produksi teks adalah hal yang sangat penting, tentunya tak lepas dari konteks sosio-kultural yang melatarbelakangi teks tersebut. (Fairclough 1995,97-100)

Untuk analisis kewacanaan, Fairclough mengemukakan bahwa analisis kewacanaan berfungsi untuk mengetahui proses produksi, penyebaran dan penggunaan teks. Dengan demikian ketiga tahapan tersebut patut dilakukan dalam menganalisis dimensi kewacanaan (Fairclough 1992, 65). Analisis kewacanaan ini juga disebut sebagai tahap interpretasi. Dalam melakukan prosedur interpretasi, Fairclough menjabarkan secara garis besar dalam dua hal, yakni terhadap teks dan situasi kontekstualnya. Dalam melakukan interpretasi terhadap teks, diperlukan empat tingkatan. Fairclough menyebut tingkatan pertama sebagai surface of utterance atau permukaan ungkapan. Tingkat ini berkaitan dengan proses di mana penafsir mentransformasikan tanda-tanda yang didapatkan menjadi frase atau kalimat dengan pemanfaatan kosakata, tata bahasa, bahkan bunyi (fonologi). Tingkatan kedua, yakni meaning of utterance atau makna ungkapan. Pada level ini ungkapanungkapan yang terkandung dalam teks mulai diberi makna dengan pemanfaatan ilmu semantik dan pragmatik. Memasuki tingkatan ketiga, yakni local coherence atau koherensi lokal, di mana makna yang terkandung dalam berbagai ungkapan kemudian dihubungkan yang dapat menghasilkan penafsiran yang sesuai dengan sekuensi atau pasangannya. Dalam hal ini, diperlukan pengetahuan tentang pragmatik dan kohesi. Level keempat yaitu text structure and point yang 
berkaitan dengan hubungan teks secara global. Tingkatan ini dapat dilakukan dengan menentukan jenis-jenis diskursus yang sedang dipahami serta tatanan wacananya dengan menggunakan representasi atau skema dari pola-pola tertentu. Setelah itu, dapat ditemukan point dari teks tersebut berupa ringkasan atau topik.

Sedangkan perihal interpretasi konteks dapat dibedakan menjadi dua macam, yakni konteks situasional dan konteks intertekstual. Konteks situasional merupakan konteks yang dapat di eksplor melalui pemahaman tatanan sosial yang bersifat institusional serta orang-orang yang melingkupi produksi. Untuk konteks intertekstual bisa diketahui melalui sejarah interaksional dari bermacammacam diskursus atau wacana. Dari peninjauan melalui sejarah interaksional maka dapat dilihat wacana apa saja yang memiliki hubungan dengan wacana dalam teks serta asumsi-asumsi yang mengikutinya yang dapat menentukan mana yang mendapat penerimaan dan mana yang mendapat penolakan (Fairclough 2001, 121).

Dalam analisis praktis sosial, Fairclough mengemukakan bahwa analisis praktis sosial didasarkan pada bahwa konteks sosial yang ada di luar teks mempengaruhi kelahiran sebuah teks/wacana. Ini merupakan tahap analisis yang ketiga setelah interpretasi, yakni eksplanasi yang menitikberatkan pada penggambaran wacara sebagai bagian dari praktik sosial serta menampilkan determinasi wacana terhadap struktur sosial serta dampak reproduktifnya terhadap struktur tersebut, baik berdampak

$\begin{array}{lrr}\text { memapankan } & \text { struktur } & \text { ataupun } \\ \text { mereformasi } & \text { struktur. } & \text { Fokus }\end{array}$
pemahaman dalam struktur sosial yang dimaksud adalah aspek-aspek yang meliputi relasi kuasa. Selain itu, praktikpraktik dan proses-proses sosial yang dijadikan tinjauan utama adalah proses serta praktik perjuangan sosial. Oleh karena itu, tahapan eksplanasi ini merupakan persoalan untuk melihat wacana sebagai bagian dari pertarungan sosial dalam sebuah matriks relasi kuasa. Fairclough menekankan dua hal yang harus diselami dalam skema eksplanasi ini yang disebut determinan dan efek. Determinan sendiri merupakan relasi kuasa yang menentukan wacana dalam proses perjuangan sosial, sedangkan yang disebut efek adalah merujuk pada dampak yang dihasilkan dari suatu wacana tertentu. Baik determinan maupun efek harus ditinjau dalam tiga level analisis organisasi sosialnya. Tiga level analisis sosiokultural ini adalah level situasional, institusional, dan sosial.

Beberapa penelitian mengenai persoalan maskulinitas telah dikaji, salah satunya adalah penelitian dilakukan oleh Restia Noviana (Noviana 2017) yang membahas mengenai maskulinitas dalam novel. Novel yang dianalisis berjudul As Seen on TV karya Christian Simamora yang merepresentasikan konsep maskulinitas melalui tokoh utama lakilakinya yang bernama Javi. Sang penulis mencoba membentuk sebuah konsep maskulinitas baru yang berbeda dari konsep-konsep maskulinitas sebelumnya. Hasil analisis ditemukan bahwa konsep maskulinitas yang dinarasikan dalam novel tersebut 
menggambarkan sosok laki-laki ideal adalah laki-laki sukses yang memiliki latar kehidupan perkotaan yang mewah dan modern serta bertubuh six pack, atletis, berotot, dan berwajah tampan. Selain suka memperhatikan penampilan, ia juga berjiwa bebas dan suka bersenangsenang dengan bersantai di beerhouse, meminum alkohol, dan menikmati seks bebas. Penelitian lain dilakukan oleh Daniel Susilo (Susilo 2015) yang membahas tentang konstruksi maskulinitas dalam teks media. Dalam artikelnya, Daniel mencoba menganalisis wacana maskulinitas yang diambil dari media berita online tentang pemerkosaan. Penelitian tersebut menggunakan metode Analisis Wacana Kritis Van Dijk terhadap konstruksi maskulinitas dalam teks media di tiga situs berita online Indonesia, Tribunnews.com, Merdeka.com, dan JPNN.com. Hal-hal yang diamati adalah tematik, skematik, semantik, sintaksis, stilistik, dan retoris. Hasil dari penelitian ini adalah situs berita online telah mengkonstruksi maskulinitas sebagai keistimewaan lakilaki dalam berita perkosaan. Selain itu, situs berita online menguatkan pandangan oposisi biner terhadap perempuan, yakni perempuan baik-baik dan perempuan tidak baik-baik melalui elemen-elemen dan sumber daya media yang dikuasainya.

Masih melalui media online, penelitian ini pun mencoba menganalisis persoalan maskulinitas dari perspektif kajian dakwah di platform Youtube. Dengan menggunakan konsep analisis yang ditawarkan Norman Fairclough, diharapkan hasil yang didapatkan adalah terungkapnya ketiga level dimensi yang meliputi deskripsi, interpretasi, serta penjelasan. Sehingga wacana maskulinitas yang disampaikan oleh pendakwah dapat dimaknai melalui teks itu sendiri, praktek wacana, dan juga praktik sosial.

\section{METODOLOGI PENELITIAN}

Penelitian ini menggunakan metode deskriptif analitik dengan mengandalkan sumber data utama yang diperoleh dari kajian ceramahceramah Ustadz Khalid Basalamah yang berada di tayangan Youtube. Teori analisis wacana kritis digunakan untuk menganalisis data ditinjau dari tiga dimensi wacana, yakni dimensi teks, dimensi diskursus, serta dimensi praktik sosial. Data yang dikumpulkan berupa tuturan-tuturan dan ungkapanungkapan yang mengandung unsur maskulinitas dari ceramah yang dibawakan Ustadz Khalid Basalamah. Tuturan dan ungkapan tersebut kemudian ditranskripkan dalam bentuk teks sehingga dapat dianalisis dengan mengaplikasikan bentuk-bentuk wacana yang terdapat dalam teks yang di produksi oleh Ustadz Khalid Basalamah. Setelah dianalisis dengan meninjau ketiga dimensi yang telah disebutkan, maka akan ditemukan suatu pemahaman mengenai konteks media dalam peran penyebaran teks tersebut, konteks yang ditangkap dari para konsumen, serta latar belakang dan praktik sosial yang dapat memunculkan teks-teks yang diproduksi tersebut.

\section{HASIL DAN PEMBAHASAN}

Ustadz Khalid Basalamah termasuk salah satu ustadz dengan jumlah subscriber terbanyak di Youtube sejak 
beliau bergabung tahun 2013. Isi cermahnya pun banyak mengkaji persoalan-persoalan dalam Islam dengan rujukan alquran dan sunnah serta pemahaman para ulama. Salah satu perosalan yang paling sering dikaji oleh beliau adalah perihal figh (aturan dan syariat dalam beribadah) dan persoalan rumah tangga. Dalam kajian rumah tangga ini, beliau sering menjabarkan kedudukan antara lakilaki sebagai suami dan perempuan sebagai istri. Dalam penelitian ini, peneliti mencoba mengambil tiga sample kajian ustadz Khalid dalam hal menjelaskan karakteristik seorang lakilaki serta kedudukannya, dimana hal ini berkaitan erat dengan persoalan maskulinitas yang ada di masyarakat. Tuturan kajian yang diambil berupa potongan video pada saat beliau menyampaikan kajian dan juga pada saat sesi tanya jawab. Judul-judul dari video tersebut diantaranya adalah; perbedaan antara laki-laki dan perempuan, mengenal sifat dan karakter laki-laki, serta laki-laki tidak boleh cengeng. Dari ketiga video tersebut, peneliti akan mencoba mengungkap makna tuturan melalui tiga tahapan dimensi yang ditawarkan Fairclough.

\subsection{Dimensi Tekstual}

Dimensi pertama adalah dimensi tekstual. Dalam dimensi tekstual, peneliti akan menggunakan analisis tema, repetisi, serta diksi. Dalam kajian-kajian yang dibawakan oleh Ustadz Khalid, beliau membahas mengenai perbedaan karakteristik antara laki-laki dan perempuan. Seperti dalam videonya yang berjudul Perbedaan Antara Laki-Laki dan
Perempuan, beliau menjelaskan seperti dalam kutipan berikut

“Ini karakter-karakter dasar laki-laki dan perempuan laki-laki gunakan akal perempuan gunakan perasaan" (0:07-0:13)

Dalam kajian ini tema dasar yang disajikan beliau adalah perbandingan perilaku antara laki-laki dan perempuan. Beliau menjelaskan bahwa seorang laki-laki mengedepankan akalnya dibandingkan perasaan. Pernyataan tersebut kemudian ditekankan kembali dengan kalimat berikutnya berupa;

"laki-laki misalnya, kita mau beli baju, ini karakter ya, secara umum, saya bicara umum, kalau ada yang berbeda berarti memang dia keluar dari umumnya ya, apa yang ada yang Allah ciptakan fitrah, kalau kita masuk ke dalam sebuah toko kemudian kita melihat baju tertentu misal baju kita senangi. Baiklah udah liat cocok, coba kayaknya cocok nih warnanya. Terus kita tanya sama pemilik toko "Saya mau beli yang ini ada ukuran XL nggak?" dia bilang, "nggak ada" kira-kira apa yang anda lakukan sebagai laki-laki? kalau saya, sama nggak kira-kira? "Baiklah kalau begitu coba saya lihat yang lain." Selesai. Nggak ada permasalahan. Nggak ada ukurannya mau diapain? Pakai akal pikiran, nggak ada, solusi, enggak ada, solusi." (0:21-1:11)

Dalam kalimatnya tersebut, beliau mencoba memberikan penekanan bahwa karakter laki-laki secara umum adalah yang demikian, jika ada laki-laki yang berbeda, atau tidak memiliki sikap yang seperti itu, maka laki-laki tersebut keluar dari sifat umum seorang laki-laki yang menurut beliau, sudah diciptakan 
kodratnya yang demikian. Sifat laki-laki pada dasarnya adalah menghadapi masalah dengan akal. Seperti yang beliau contohkan ketika sedang membeli baju, maka jika tidak ditemukan ukuran yang pas maka mereka akan mencoba mencari yang lain secara langsung.

Dalam kajiannya yang lain yang berjudul Mengenal Sifat dan Karakter Laki-laki beliau juga memberikan pengulangan yang sama mengenai kalimatnya.

"Sekarang kita pindah ke karakter laki-laki ada kurang lebih 13 poin yang saya susun nya yang pertama akal pikiran dominan."

Dari ketiga belas poin, beliau menyebutkan akal pikiran dominan adalah yang pertama. Kegiatan tersebut seolah menunjukkan bahwa Ustadz Khalid memandang maskulinitas seorang pria dilihat dari bagaimana mereka bersikap mengedepankan akal dibanding perasaan. Jika seorang lakilaki, maka orang tersebut seharusnya memiliki sikap tersebut, karena menurut beliau itu adalah fitrahnya sebagai laki-laki.

Dalam suatu penelitian, Kurnia menjabarkan representasi maskulinitas dalam iklan. Dalam analisisnya, maskulinitas adalah imaji kejantanan, ketangkasan, keperkasaan, keberanian untuk menantang bahaya, keuletan, keteguhan hati, keringat yang menetes, otot laki-laki yang menyembul, atau bagian tubuh tertentu dari kekuatan daya tarik laki-laki yang terlihat secara ekstrinsik (Kurnia 2004, 22). Dengan kata lain, maskulinitas bisa didefinisikan sebagai sesuatu yang bersifat kelelakian. Hal ini sejalan dengan poin yang dijelaskan oleh Ustadz Khalid bahwa tingkat kemaskulinan seorang laki-laki adalah ditampilkan dari pembawaan mereka.

Jika dilihat dari pemilihan kata yang digunakan oleh Ustadz Khalid, beliau sering menggunakan kata "akal" pada saat menjabarkan karakteristik seorang laki-laki. Begitupun pada saat beliau menjabarkan kedudukan seorang lakilaki terhadap perempuan, seperti dalam kutipan ceramah Perbedaan Antara Laki-laki dan Perempuan berikut;

".....Wibawa, orangnya punya wibawa, orangnya di rumah teratur, orangnya begini karena dia merasa itu pemimpin, tidak boleh bapak-bapak di dalam karakter ini merendah berlebihan pada istrinya...." (8:00-8:15)

Beliau menggunakan kata wibawa, dan dilanjutkan dengan frasa merendah berlebihan. Kata wibawa diulang dua kali dalam kalimat tersebut, dimana beliau menunjukkan penekanan dari kata wibawa tersebut untuk mendeskripsikan karakter seorang lakilaki. Menjadi seorang laki-laki seharusnya berada di kedudukan diatas seorang perempuan. Tidak seharusnya seorang perempuan mengungguli seorang laki-laki, begitupun laki-laki tidak patut merendahkan diri dihadapan perempuan. Kalimat serupa juga terdapat dalam ceramahnya yang berjudul Laki-laki Gak Boleh Cengeng, beliau juga mengulangi kalimat yang senada dengan kalimat di ceramah sebelumnya.

“....yang pertama sekali Saya menyarankan Anda, saran dari laki-laki ke laki-laki, prinsip lah, dan jangan merendahkan diri dihadapan wanita...."(1:26-1:41) 
Kalimat tersebut dituturkan ketika ada seorang penanya yang sedang bersedih mengutarakan keluh kesahnya bahwa istrinya telah memintanya untuk menceraikannya, padahal ketika pergi, istrinya berpamitan mengunjungi orang tuanya yang sedang sakit. Namun beberapa saat setelah itu, suami di telepon oleh istrinya dan mengatakan bahwa ia tidak ingin kembali lagi ke rumah, jika ingin mencari wanita yang lain maka dipersilahkan. Seketika yang pertama kali disarankan Ustadz Khalid adalah untuk tidak merendahkan diri dihadapan wanita. Beliau melanjutkan supaya tak perlu menangis dan bersedih, karena pada hakikatnya, seorang pria dalam Alquran pun dipersilahkan untuk melakukan poligami, sehingga seharusnya tidak masalah jika memang istrinya minta cerai dan mempersilahkan agar suami mencari lagi yang baru. Tidak seharusnya laki-laki menjadi bersedih karena hal itu.

Pernyataan ini senada dengan apa yang dijelaskan oleh Wood mengenai perspektif maskulinitas yang dibentuk oleh media. Wood menjabarkan bahwa kuatnya media menciptakan dan mendeskripsikan stereotipe mengenai laki-laki dan perempuan. Media menggambarkan sosok laki-laki dan maskulinitas sebagai mereka yang agresif, dominan, dan terlibat dalam berbagai kegiatan yang membutuhkan keputusan. Media menggambarkan itu sebagai imbalan dari sisi maskulin yang laki-laki miliki.

\subsection{Dimensi Kewacanaan}

Berlanjut mengenai analisis kewacanaan. Analisis kewacanaan digunakan untuk mengungkap proses teks terbentuk, diantaranya adalah bagaimana teks wacana diproduksi, bagaimana teks wacana disebarkan, dan bagaimana teks wacana dikonsumsi. Ketiga proses ini sangatlah penting untuk dianalisis untuk dapat memaknai suatu wacana yang muncul dalam teks. Pertama adalah produksi teks. Kajian bertema kepribadian seorang laki-laki yang sudah dibahas diatas diproduksi oleh Ustadz Khalid Basalamah. Beliau menghabisnya masa mudanya untuk belajar. Setiap hari beliau mendalami ayat-ayat Alquran, kitab, dan hadist. Sampai akhirnya beliau menuntut ilmu di Universitas Madinah, Arab Saudi. Setelah selesai kuliah S1 di Madinah, beliau meneruskan pendidikan S2 di Universitas Muslim Indonesia di Makassar. la pun mengambil pendidikan S3 di Universitas Tun Abdul Razak di Malaysia.

Ustadz Khalid Basalamah berdakwah di mana-mana. Dari satu masjid ke masjid lain. Bahkan ia sering diundang untuk berdakwah sampai ke luar negeri. Dari ceramahnya, ustadz ini terkenal dengan dakwahnya yang tegas. Berbagai macam kitab, dalil, dan hadist yang kuat dijadikan materi ceramah. Walau ada saja yang tidak sependapat, banyak orang yang tercerahkan dengan ceramahnya. Beliau memberikan ceramah dan kajian secara independen. Tidak ada kontrak kerjasama dengan media televisi, sehingga segala bentuk dokumentasi pun dilakukan oleh pribadi. Segala aktifitas ceramahnya diunggah di akun Instagram resmi serta kanal Youtube milik beliau. Tidak ada keterlibatan media televisi untuk menayangkan dakwahnya. Oleh karena itu, segala tuturan yang beliau ucapkan bukanlah 
suatu giringan opini dari media tertentu. Ustadz Khalid adalah pendakwah yang beraliran ahlu sunnah wal jama'ah dimana dasar-dasar yang harus dipegang adalah Alquran dan Hadits Shohih. Sedangkan, yang banyak dilakukan oleh media televisi adalah memberikan sebuah tema dan menentukan apa-apa saja yang harus dijelaskan bahkan dalam durasi waktu yang cukup singkat, bahkan tidak jarang pula yang memasukkan promosi produk-produk tertentu didalam kajiannya sehingga terkadang kajian yang dibawakan mengikuti suatu sponsor tertentu yang mendanai acara mereka.

Proses kedua yakni penyebaran teks. Teks yang dituturkan oleh Ustadz Khalid disebarkan melalui platform Youtube, beberapa juga tersebar melalui Instagram yang hanya potonganpotongan inti saja. Selain dari akun resmi Ustadz Khalid, banyak juga akunakun dakwah lain yang ikut mempublikasikan ulang dari dakwah beliau, baik secara keseluruhan maupun pada inti dari topik pembahasan. Berbeda dengan televisi yang memiliki keterbatasan waktu yang singkat, Youtube merupakan media yang memberikan batasan waktu lebih panjang. Durasi paling lama video yang dapat dipublikasikan adalah sepuluh jam, sehingga kegiatan kajian yang dilakukan bisa sangat fleksibel dan terperinci.

Proses yang ketiga yakni konsumsi teks. Proses analisis ini melibatkan kepada siapa saja yang mengkonsumsi media tersebut. Dalam kajian Ustadz Khalid, jika ditinjau dari komentakomentar yang ada di videonya, maka akan terlihat bahwa para konsumen memang banyak yang setuju dengan apa yang disampaikan oleh Ustadz. Tidak sedikit pengguna perempuan yang berkomentar positif dan membenarkan apa yang disampaikan oleh Ustadz. Meskipun kajiannya membicarakan perbandingan yang signifikan antara laki-laki dan perempuan dimana dalam konteks kajiannya, laki-laki seolah lebih dimuliakan dibandingkan perempuan, namun komentar yang ada dan ditulis oleh perempuan justru menyepakati hal tersebut. Seperti contohnya komentar yang ditulis oleh akun Endangsitisopiah 1808

"Iya bner bgt. Aku yg ngalamin klo laki" mrendah itu aku merasa dia tunduk pada ku..maafkan aku ya Allah"

Dia menyikapinya dengan bercermin kepada dirinya sendiri dan memahami bahwa yang dituturkan oleh Ustadz adalah benar baginya. Begitu juga dengan akun Kimzani Lestari yang berkomentar,

"Lailahailallah... Bener sekali. Saya sangat setuju dengan ceramah ustadh"

Pun membenarkan apa yang telah dijelaskan oleh Ustadz. Meskipun ada juga yang perempuan yang kurang setuju, namun ia menyampaikannya dengan santai dan mencoba mengkoreksi dirinya sendiri, sperti komentar yang ditulis oleh akun Shafira Nurlaela yang berbunyi

"Yang nyimpen sms sampai2 bertahun2 salut bgt... Aku mah paling gk tahan klo hp gak bersih pengennya maen hapus2 aja hha... Semua mulai dari chat wa, sms, sms terkirim, catatan panggilan smua dihapus, termasuk history penjelajahan internet. Kesukaan orang beda - beda. Padahal itu penting 
kan bwt catatan semisalnya ada kejadian kejahatan yg tidak diinginkan. Amit amit sih... Smoga Allah melindungi kita semua...."

Terdapat kalimat "Kesukaan orang beda-beda" dalam komentar tersebut, menandakan bahwa dia kurang begitu setuju dengan tuturan Ustadz. Namun kalimat berikutnya justru mengingatkan pada dirinya sendiri bahwa sebetulnya segala sesuatu memang harus disimpan apalagi catatan penting untuk bejagajaga jika sewaktu-waktu muncul kejadian yang tak terduga.

Dari penjelasan tersebut dapat diketahui bahwa konsumen video-video kajian Ustadz Khalid adalah mereka yang memiliki pemikiran yang sepaham. Mayoritas komentar yang ditemukan adalah komentar dari akun perempuan, yang seharusnya kedudukan mereka berada di bawah jika dibandingkan dengan penjelasan Ustadz mengenai laki-laki. Namun banyak dari mereka yang tidak keberatan dengan hal tersebut, karena mereka juga menyadari apa yang ada pada diri mereka sejalan dengan apa yang dituturkan. Sehingga para konsumen akan dengan mudah berintrospeksi diri dan juga semakin tertarik untuk mengikuti kajian-kajian Ustadz Khalid yang lain.

\subsection{Dimensi praktis sosial}

Dalam konteks gender, di era modern kemudian muncul gagasangagasan baru, salah satunya adalah perluasan hak perempuan sebagai manusia bebas serta perempuan memiliki kesamaan hak dengan laki-laki dalam berbagai aspek kehidupan seperti hak politik, hak pendidikan, hak memperoleh pekerjaan, hak kesehatan, dan sebagainya. Tanpa mengabaikan kemajuan tersebut, secara umum harus diakui bahwa kultur tersebut belum diakui sepenuhnya dari masyarakat saat ini. Fenomena seperti ini juga berlaku ketika membaca masyarakat Indonesia. Secara keseluruhan masyarakat Indonesia merupakan masyarakat patriarkis. Sistem patriarkis di Indonesia berjalan baik pada masyarakat yang menganut sistem keluarga patrilineal, bilateral, maupun matrilineal, diantaranya Batak, Jawa dan Minang. Masyarakat dengan sistem keluarga patrilineal dan bilateral yang bersifat patriarkis mungkin terlihat wajar dan tidak susah untuk dijelaskan. Namun hal ini akan terlihat tidak wajar pada saat masyarakat Minang yang jelas-jelas menganut sistem keluarga matrilineal ternyata juga bersifat patriarkis dalam praktiknya. Tetapi begitulah kenyataannya, di masyarakat tersebut meskipun pemilikan dan pewarisan harta keluarga mengalir dari garis keturunan perempuan, namun pengambilan keputusan keluarga tidak berada pada ibu, tetapi pada saudara laki-laki dari ibu.

\section{SIMPULAN}

Dari kajian yang dibawakan oleh Ustadz Khalid Basalamah mengenai karakteristik laki-laki serta kedudukannya di hadapan perempuan, dapat diketahui bahwa Ustadz Khalid memproduksi teks tersebut dengan banyak menekankan wibawa dan akal yang dimiliki oleh laki-laki. Seorang lakilaki di hadapan perempuan seharusnya menunjukkan wibawanya, melalui karakternya yang tidak terlalu terbawa perasaan, namun lebih mengedepankan logika yang secara dasar dimiliki laki-laki. Pemilihan kata 
yang digunakan oleh Ustadz Khalid lebih bersifat nasihat dan saran terhadap laki-laki, beliau menjelaskan bahwa menjadi seorang laki-laki secara umum seharusnya seperti ini, tentunya apa yang beliau sampaikan tersebut mengikuti Alquran dan Hadith. Proses penyebaran teks yang disampaikan oleh Ustadz Khalid tersebar melalui media online yakni Youtube, tidak ada kerjasama dengan media televisi, artinya proses penyebaran dilakukan secara independen, sehingga apa yang disampaikan beliau tidak terpengaruh dengan latar belakang dari media tertentu yang berpotensi menggiring opini-opini yang dimaksudkan dari media itu sendiri. Proses sosiokultural teks yang disampaikan Ustadz Khalid dapat ditinjau dari aspek sosial di Indonesia. Meskipun dalam kemajuan zaman saat ini gagasan persamaan hak antara perempuan dan laki-laki sudah sangat ramai dibahas, namun dalam praktiknya Indonesia masih menganut sistem patriarki bahkan dalam sistem keluarga matrilineal praktek patriarki masih dilakukan. Hal itulah yang menjadikan kajian yang dibawakan oleh Ustadz Khalid berjalan beriringan dengan mindset sosial masyarakat Indonesia. Sehingga para konsumen yang mendengarkan atau menonton kajiannya dipastikan setuju dengan yang disampaikan beliau. Bahkan komentar para perempuan yang kurang diuntungkan dalam kajiannya merasa sependapat dengan Ustadz Khalid. Dengan demikian wacana yang muncul dalam teks kajian Ustadz Khalid yang telah dianalisis berupa ideologi patriarki.

Saran bagi penelitian selanjutnya bahwa konteks wacana dalam media selalu mengalami pergeseran yang disebabkan oleh betapa kuatnya media mengendalikan wacana itu sendiri. Oleh karena itu, sangat direkomendasikan agar dapat dilakukan penelitian yang mengambil objek teks penceramah atau dai yang tidak hanya melakukan ceramah di media online saja, tetapi juga melakukannya di televisi. Maka dari kedua perbandingan tersebut akan dapat dipelajari serta dianalisis wacana-wacana yang dihasilkan dari kedua media yang berbeda. Selanjutnya, peneliti bisa membandingkan kedua wacana yang dihasilkan dari media yang berbeda. Sehingga akan dapat ditarik kesimpulan siapakah yang memiliki kekuasaan dalam wacana yang dihasilkan, apakah penceramah atau justru media yang menayangkan.।

\section{DAFTAR PUSTAKA}

Doyle, James A. 1989. The Male Experience. 2nd Editio. Dubque: William C. Brown Publisher.

Fairclough, Norman. 1992. Discourse and Sosial Change. Cambridge: Polity Press.

---1 1995. Critical Discourse Analysis: The Critical Study of Language. London dan New York: Longman.

- - . 2001. Language and Power. England: Pearson Educated Limited.

Jannah, L. (2016). Maskulinitas dalam Iklan Produk Perawatan Wajah untuk Laki-Laki (Analisis Wacana Maskulinitas Dalam Iklan Garnier MEN Versi Two Men's World, Versi Urban Hero dan Versi Joe Taslim).

Kurnia, Novi. 2004. "Representasi Maskulinitas Dalam Iklan." Jurnal 
IImu Sosial Dan Politik 8 (1).

Noviana, R. 2017. "Maskulinitas Dalam Novel." 2017. http://repository.umy.ac.id/bitstre a.

Susilastuti, Dewi H. 1993. Gender Ditinjau Dari Perspektif Sosiologi, Dalam Fauzie Ridjal Dkk. Dinamika G. Yogyakarta: Tiara Wacana.

Susilo, D. $2015 . \quad$ "Konstruksi Maskulinitas Dalam Teks Media: Analisis Wacana Maskulinitas Dalam Berita Pemerkosaan Di Situs Berita Online." In International Conference of Language, Culture, and Society, 25-26. Katubi \& Imelda.

Umar, W. 2006. Konstruksi feminitas dan maskulinitas dalam media massa: Analisis wacana terhadap Majalah Femina. Doctoral dissertation: Universitas Gadjah Mada.

Wijayanti, Sri Indah. 2019. “Representasi Perempuan Dinamis Dalam Iklan Wardah Instaperfect 'For Your Unstopable Move' Versi Raline Shah." Universitas Bakrie.

Wood, Julia T. 1984. Gendered Lives: Communication, Gender, and Culture. Boston: Wadsworth Publishing.

Yuliyanti, Friska Dewi. Atwar Bajari. Slamet Mulyana. 2017. "Representasi Maskulinitas Dalam Iklan Televisi Pond's Men \#Lelakimasakini (Analisis Semiotika Roland Barthes Terhadap Representasi Maskulinitas)." Jurnal Komunikasi 9 (1).

Website

Wink. (2018-01). Profil dan Biografi Ustadz Kholid Basalamah. https://www.biografiku.com/biografidan-profil-ustadz-khalid-basalamah/ diakses pada: 15 Desember 2019

Yuk Hijrah. (2016-12). Perbedaan Antara Laki-Laki dan Perempuan. https://www.youtube.com/watch?v=Of GAXqEGXM4 diakses pada: 13 Desember 2019

Wandi Susanto. (2019-04). Laki-Laki Gak Boleh Cengeng.

https://www.youtube.com/watch?v

=19eAOFTffaE diakses pada: 13

Desember 2019

Pasukan Tobat. (2018). Mengenal Sifat dan Karakter Laki-Laki. https://www.youtube.com/watch?v=9 DSTY2OSADQ diakses pada: 13 Desember 2019

Ayat Kursi Network. (2016-07). Aqidah Salafi Ustadz Khalid Basalamah. https://www.ayatkursi.com/2016/07/aqidah-salafiustadz-khalid-basalamah.html diakses pada: 15 Desember 2019 
Vol. 2 No. 2

December 2020

e- ISSN 2685 - 0559

p- ISSN 2684 - 673X 